\title{
Effect of Socio-demographic Factors on the Consistency of Condom Use among Female Sex Workers in Tulungagung District, East Java
}

\author{
Ainun Hanifa'), Ari Natalia Probandari²), Eti Poncorini Pamungkasari²) \\ 1)Diploma III Program in Midwifery, Tulungagung University \\ 2)Faculty of Medicine, Sebelas Maret University
}

\begin{abstract}
Background: Sexually Transmitted Infection (STI) is common among female sex workers (FSW). STI can be cured by correct diagnosis and prompt treatment. Correct treatment depends on the specific causal infection agent, as well as host and environmental factors. This study aimed to examine the effect of socio-demographic factors on the consistency of condom use among female sex workers in Tulungagung district, East Java.

Subjects and Method: This was an analytic and observational study using cohort design. It was conducted at Ngujang and Gunung Bolo prostitution areas, Tulungagung, East Java, from November to December 2017. A total sample of 90 female sex workers was selected for this study. The dependent variable was consistency of condom use. The independent variables were age, marital status, education, urban-rural residence, and exposure to information from health personnel. The data were collected by a set of questionnaire and diary. The data were analyzed by chi square and logistic regression model.

Results: Bivariate analysis with chi square test showed that female sex workers working at Ngujang prostitution area $(\mathrm{OR}=11.7 ; 95 \% \mathrm{CI}=11.7$ to $95.9 ; \mathrm{p}<0.001)$, widow $(\mathrm{OR}=1.28 ; 95 \% \mathrm{CI}=$ 1.12 to $1.45 ; \mathrm{p}=0.012)$, education level lower than senior high school $(\mathrm{OR}=1.30 ; 95 \% \mathrm{CI}=1.13$ to $1.49 ; \mathrm{p}=0.005$ ), were more likely to use condom consistently than those working at Gunung Bolo, married/ single, education level senior high school or higher, respectively. Female sex workers aged $\geq 35$ years old $(\mathrm{OR}=0.77 ; 95 \% \mathrm{CI}=0.68$ to $0.89 ; \mathrm{p}=0.006)$, rural origin $(\mathrm{OR}=-0.65 ; 95 \% \mathrm{CI}=$ 0.2 to $2.12 ; \mathrm{p}=0.474)$, receiving health information from health personnel $(\mathrm{OR}=0.79 ; 95 \% \mathrm{CI}=$ 0.70 to $0.90 ; \mathrm{p}=0.017$ ), were less likely to use condom consistently than aged $<35$ years old, urban origin, not receiving information from health personnel.

Conclusion: Female sex workers working at Ngujang prostitution area, widow, education level less than high school, were more likely to use condom consistently than at Gunung Bolo, married/ single, education level senior high school/higher, respectively.
\end{abstract}

Keywords: sexually transmitted infection, consistent use of condom, socio-demographic factors

\section{Correspondence:}

Ainun Hanifa. Diploma III Program in Midwifery, Tulungagung University.

Email: arfabachtiar13@gmail.com.

\section{BACKGROUND}

Sexually Transmitted Infection (STI) is a community health problem throughout the world. STI is an infection caused by more than 30 bacteria that have direct impacts toward the sexual and reproductive health. Both the high prevalence and the incidence of STI are related to the practice of STIprevention behaviours that are still low such as the low rate of condom use on the risky sexual behaviours and the high rate of promiscuity. The incidence of STI mostly occurs among the groups with risk and one of these groups is Female Sex Workers (FSW) (Sembiring et al., 2012).

FSW is divided into two categories. The first category is direct sex workers, namely the female sex workers who openly 
offer sexual relationship commercially both in the streets and in the prostitutions or the ex-prostitutions area. Then, the second category is indirect sex workers, namely the female sex workers who offer sexual relationship commercially and covertly because they have main occupation in the entertainment centres such as massage house, karaoke house, and others (Li et al., 2012).

STI might be cured if diagnosis is conducted accurately and if the patients are medicated immediately. The medication of STI should be adjusted to the factors that have caused the infection. The factors that cause the occurrence of STI are agent, host, and environment. In relation to these factors, socio-demographic conditions can be one of the factors cause the occurrence of STI as well. One of the effective strategies to prevent the STI spreading and to protect the groups with risk, including the FSW, from the STI occurrence is the consistent use of condom (Bankole et al., 2007).

The consistent use of condom refers to the use of condom reported by the FSW in performing sexual transaction with their sexual customers. The consistent use of condom might be measured by using the ratio of condom use to the number of sexual intercourse that is performed with the category $>50.00 \%$. On the other hand, the consistent use of condom might also be measured from the latest sexual intercourse as the most general period for viewing the consistent use of condom (Bankole et al., 2007; Budiono, 2012; Fonner et al., 2014).

\section{SUBJECTS AND METHODS}

This was an analytic and observational study using the retrospective cohort design. The population in this study was all of the FSW who settled in Tulungagung District.
The sample in this study was 69 FSW who settled in Ngujang Ex Red-Light District and 21 FSW who settled in Gunung Bolo Red Light District.

The purposive sampling technique was used in selecting the two sites, namely Ngujang Ex Red-Light District and Gunung Bolo Red-Light District. Then, the total sampling technique was used in selecting the subjects by gathering all subjects in the two sites. The inclusion criteria of the study were the FSW were willing to be respondents, the FSW settled in the sites during the period of the study, and the FSW could read and write. On the other hand, the exclusion criterion was the FSW withdrew herself before the study had been completed.

\section{RESULTS}

Based on the results displayed in Table 1, it could be seen that most of the FSW in Ngujang Ex Red-Light District were consistent in using condom (98.60\%). All of the young FSW ( $<35$ years old) were consistent in using condom. The widow FSW were also consistent in using condom (78.50\%). The percentage of FSW who came from the village and the city was also similar in terms of consistency in using condom. All of the FSW with high educational background consistently used condom as well. The FSW attained information regarding the use of condom from both the Internet and the medical staff.

Type of red-light district (OR=11.50; $95 \% \mathrm{CI}=11.70$ to $95.90 ; \mathrm{p}<0.001)$, marital status of $\mathrm{FSW}(\mathrm{OR}=1.28 ; 95 \% \mathrm{CI}=1.12$ to $1.45 ; \mathrm{p}=0.012$ ), and educational background of $\mathrm{FSW}(\mathrm{OR}=1.30 ; 95 \% \mathrm{CI}=1.13$ to $1.49 ; \mathrm{p}=0.005$ ) increased the use of condom and were statistically significant. 
Hanifa et al./ Effect of Socio-demographic Factors on the Consistency of Condom Use

Table 1. The socio-demographic variables on the use of condom

\begin{tabular}{|c|c|c|c|c|c|c|c|}
\hline \multirow{3}{*}{$\begin{array}{c}\text { Socio-demographic } \\
\text { variables }\end{array}$} & \multicolumn{4}{|c|}{ The use of condom } & \multirow{3}{*}{$\mathbf{O R}$} & \multirow{3}{*}{$95 \% \mathrm{CI}$} & \multirow[t]{3}{*}{$\mathbf{P}$} \\
\hline & \multicolumn{2}{|c|}{ Consistent } & \multicolumn{2}{|c|}{ Inconsistent } & & & \\
\hline & $\mathbf{n}$ & $\%$ & $\mathbf{n}$ & $\%$ & & & \\
\hline \multicolumn{8}{|l|}{ Type of Red-Light District } \\
\hline Ngujang Ex Red-Light District & 68 & 98.60 & 1 & 1.40 & 11.50 & 11.7 to 95.9 & $<0.001$ \\
\hline Gunung Bolo Red-Light District & 8 & 38.10 & 13 & 61.90 & & & \\
\hline \multicolumn{8}{|l|}{ Age } \\
\hline Young $(<35$ tahun $)$ & 28 & 100.00 & $\mathrm{o}$ & 0.00 & 0.77 & 0.68 to 0.89 & 0.006 \\
\hline Old ( $\geq 35$ tahun) & 48 & 77.40 & 14 & 22.6 & & & \\
\hline \multicolumn{8}{|l|}{ Marital Status } \\
\hline Unmarried/Married & 25 & 100.00 & $\mathrm{o}$ & 0.00 & 1.28 & 1.12 to 1.45 & 0.012 \\
\hline Widow & 51 & 78.50 & 14 & $21 . .50$ & & & \\
\hline \multicolumn{8}{|l|}{ Educational Background } \\
\hline Elementary & 47 & 77.00 & 14 & 23.00 & 1.30 & 1.13 to 1.49 & 0.005 \\
\hline High & 29 & 100.00 & $\mathrm{O}$ & 0.00 & & & \\
\hline \multicolumn{8}{|l|}{ Origin } \\
\hline Rural Origin & 41 & $82.00 \%$ & 9 & 18.00 & 0.65 & 0.20 to 2.12 & 0.474 \\
\hline Urban Origin & 35 & $87.50 \%$ & 5 & 12.50 & & & \\
\hline \multicolumn{8}{|l|}{ Information Source } \\
\hline Media (electronic, print) & 23 & 100.00 & $\mathrm{o}$ & 0.00 & 0.79 & 0.70 to 0.90 & 0.017 \\
\hline Medical staff & 53 & 79.10 & 14 & 20.90 & & & \\
\hline
\end{tabular}

Table 2. The results of multivariate analysis using the logistic regression

\begin{tabular}{lcc}
\hline \multicolumn{1}{c}{ Variables } & OR & p \\
\hline Type of Red-Light District & 0.021 & 0.001 \\
Age & $<0.001$ & 0.998 \\
Information Source & $<0.001$ & 0.998 \\
\hline
\end{tabular}

Based on the results of multivariate analysis using the logistic regression, it was found that there were 3 variables that belonged to the model namely type of redlight district, age, and information source. One of these variables was statistically significant, it was the type of red-light district with $\mathrm{p}=0.001$ thus, there was the effect of the type of red-light district toward the consistent use of condom.

\section{DISCUSSION}

1. The effect of the type of red-light district toward the consistent use of condom

Based on the results displayed in Table 1, it was found that most of the FSW in Ngujang
Ex Red-Light District consistently used condom (68 respondents or 98.60\%) while the FSW in Gunung Bolo Red-Light District did not consistently used condom (13 respondents or $61.90 \%$ ) with $\mathrm{p}<0.001$. It meant there was the effect of the type of red-light district toward consistent use of condom.

The factor of cooperation is heavily associated to the consistent use of condom, such as the red-light district (legal or illegal), cash or electronic payment, and number of sex partner. The FSW with low commercial rate very rarely reported the number of sexual partner and the use of condom because they tended to display economic burdens (Graham et al., 2014). 
Journal of Epidemiology and Public Health (2016), 1(2): 133-139

https://doi.org/10.26911/jepublichealth.2016.01.02.07

This finding was in accordance with the type of red-light district in which most of the FSW in Ngujang Ex Red-Light District (the representation of legal redlight district) consistently used condom because there was structured and scheduled elucidation and examination on VCT, STI, and even HIV. As a result, these FSW were more careful and more consistent in using condom in comparison to the FSW working in Gunung Bolo Red-Light District. Most of the FSW in Gunung Bolo Red-Light District (the description of illegal red-light district) were not consistent in using condom because they did not obtain regular elucidation or information and examination on VCT, STI, and even HIV, thus they felt healthy and kept conducting risky sexual transaction.

\section{The effect of the age of FSW toward the consistent use of condom}

Based on the results displayed in Table 1, it was found that most of the FSW were $\geq 35$ years old and consistently used condom (77.40\%) with $\mathrm{p}=0.006$.

The older the FSW is, the more increasing the behavior of using condom consistently will be. However, some of the old FSW did not consistently use condom in comparison to the young FSW who consistently used condom. The old FSW is highly possible to have been working in such a long time and they certainly have many sexual partners. The high number of sexual partners that they have make these FSW vulnerable to not consistently use condom and to have risky sexual behaviors (Mahaputra et al., 2013).

The old FSW in this study were less inclined to serve their sexual partners every day; however, in accumulation they had higher number of sexual partners. Due to the factors of economic demands, the old FSW were likely to serve their sexual partners perfunctorily without making any selection so that some of them did not use condom consistently. However, some other of these FSW still consistently use condom.

3. The effect of the marital status of FSW toward the consistent use of condom

Based on the results displayed in Table 1, it was found that most of FSW (51 respondents or $78.50 \%$ ) were widow and divorced and they consistently used condom with $\mathrm{p}=0.012$. This finding was significant.

The FSW low consistent condom use are those who have been older, who use to be married, who have been working as sexual workers for $\geq 10$ years, and who conduct sexual transactions around three times or more within one week (Mahaputra et al., 2013).

Most of the FSW in this study were widow and divorced and they were categorized as the risk group. They decided to work as sexual workers due to the economic demands. Consequently, they surrendered to the demand that their sexual partners proposed with regards to the type of sexual relationship, the consumption of alcohol, and even the use of condom. The reason was that these FSW wanted to get as many customers as possible in order to increase their income without considering the other matters. Such case is often found among the FSW who work in the illegal red-light district, in this case was Gunung Bolo, because the practice of commercial sexual relationship that had been performed was not well organized.

\section{The effect of the educational background of FSW toward the consistent use of condom}

Based on the results displayed in Table 1, in relation to educational background it was found that most of the FSW who had completed their elementary education (elementary school and junior high school 
graduates) consistently used condom (77.00\%) with $\mathrm{p}=0.005$.

The higher the educational level of the FSW is, the more consistent the behaviour of using condom will be. The behavior of using condom consistently can be seen from the last sexual relationship that serves as the most general temporary period for the measurement of condom use (Fonner et al., 2014).

Almost all of the FSW in this study completed the elementary education which as equal to elementary school and junior high school degree. The FSW who did not consistently used condom turned out to be the graduates of elementary school or not finishing their elementary school degree. These FSW had lower understanding toward the importance of elucidation that had been provided by the medical staff especially the FSW who worked in the illegal red-light district (Gunung Bolo). They came to the red-light district only to work as sexual workers and earn sufficient income in order to meet their needs. However, there were some of these FSW who had understood the risk of their job although they were only elementary school graduates. Most of the FSW who worked in the ex red-light district were often provided with elucidation and medical examination so that they would be more careful in performing sexual transaction in comparison to the FSW who worked in the illegal red-light district.

\section{The effect of the information source of FSW toward the consist- ent use of condom}

Based on the results displayed in Table 1, most of the FSW attained information from the medical staff and consistently used condom (79.10\%) with $\mathrm{p}=0.017$.

The counseling sessions, both the brief ones and the interactive ones, successfully decreased the incidence of
STI/HVI for more than 50\%. The skills of negotiation were necessary in order to ensure that the FSW were able to convince their sexual partners to cooperate in consistently using condom. In the same time, the FSW could also be taught to negotiate the consistent use of condom to their sexual partners through the training or the elucidation by the medical staff.

In this study, most of the FSW who consistently used condom used to attain information from the medical staff. The reason was that the information provided by the medical staff had been easier to digest rather than the information provided by the printed or the electronic media which is not accountable.

The FSW consistently used condom were the ones who worked in the legal redlight district and who had the scheduled and structured complete elucidation, counseling, or information form the medical staff in comparison to the FSW who worked in the illegal red-light district (Gunung Bolo) who did not attain complete information regarding the condom use. These group of FSW were also more able to negotiate the safe sexual relationship to their sexual partners without having to be burdened by the excessive economic demands.

\section{Multivariate Analysis}

Based on the results of multivariate analysis by using the logistic regression, it was found that out of 6 significant variables within the bivariate analysis there were only 3 variables that was categorized into the model namely the type of red-light district with $\mathrm{p}=0.001$, the age of FSW with $\mathrm{p}=0.098$, and the information source of FSW with $\mathrm{p}=0.998$.

The higher the number of FSW who work in the legal red-light district (Ngujang Ex Red-Light District) was, would increase the behaviour of using condom consistently 
Journal of Epidemiology and Public Health (2016), 1(2): 133-139

https://doi.org/10.26911/jepublichealth.2016.01.02.07

by 0.021 times. The other 3 variables were not included into the model because the they had relatively extreme precision value hence they should be dropped from the model.

The multivariate analysis indicated that the FSW who worked in the legal redlight district, in this case Ngujang Ex RedLight District, consistently used condom in comparison to the FSW who worked in the illegal red-light district. This indication is supported by the results of the study by Mahaputra et al. (2013) which showed that more than two-third FSW are involved in a sexual relationship with their sexual partners and that there is high rate on the consistent use of condom between the FSW and their commercial sexual partners, however, the rate is remain low on the consistent use of condom between the FSW and their non-commercial sexual partners (such as boy friend) due to the trust toward their customers.

The FSW who have been working for 10 years or more showed lower number of sexual partners in comparison to the younger FSW. As a result, the older FSW give up to their sexual partners' demand regarding the type of sexual relationship and the use of condom.

Most of the FSW who work in Gunung Bolo Red-Light District are $\geq 35$ years old, complete elementary education degree, and only have information regarding the use of condom from the medical staff. Gunung Bolo itself is considered as illegal red-light district and, as a consequence, the FSW in this red-light district have not been scheduled to VCT and STI/HIV examination. Due to the absence of the examination, the FSW still feel that they are healthy and they keep performing sexual transactions.

\section{REFERENCES}

Bankole A, Ahmed FH, Neema S, Ouedraogo C, Konyani S (2007). Knowledge of correct condom use and consistency of use among adolescents in four countries in Sub-Saharan Africa: African Journal of Reproductive Health, 11 (3).

Budiono I (2012). Konsistensi Penggunaan Kondom Oleh Wanita Pekerja Seks/ Pelanggannya. Kemas: Jurnal Kesehatan Masyarakat 7 (2): 97-101.

Department Of Health And Human Services. Condoms and STDs: Fact Sheet for Public Health Personnel: Centers for Disease Control and Prevention (CDC).

Febiyantin C, Kriswiharsi KS (2011). Fak tor-faktor yang berhubungan dengan Kejadian infeksi menular seksual (IMS) pada wanita pekerja seksual (WPS) usia 20-24 tahun di Resosialisasi argorejo semarang. Kesmas: Jurnal Kesehatan Masyarakat UDINUS, 1(12).

Fonner FA, Kennedy CE, O'Reilly KR, Sweat MD (2014). Systematic assessment of condom use measurement in evaluation of HIV prevention interventions: need for standardization of measures: AIDS Behav NIH Public Access 18(12).

Graham SM, Raboud J, Jaoko W, Mandaliya K, McClelland RS, Bayoumi AM (2014). Changes in Sexual Risk Behavior in the Mombasa Cohort: 19932007: Research Article. PLoS ONE, 9(11).

HandlovskyaI, Bungaya V, Kolarb K (2012). Condom use as situated in a risk context: women's experiences in the massage parlour industry in Vancouver, Canada. Culture, Health \& Sexuality, 14(9): 1007-1020.

Jie W, Xiaolan Z, Ciang L, Moyer E, Hui W, Lingyao H (2012). A Qualitative 
Exploration of Barriers to Condom Use among Female Sex Workers in China. PLoS ONE, 7(10): e46786.

Karyati S (2011). Faktor-Faktor Yang Mempengaruhi Konsistensi Wanita Penjaja Seks Dalam Pemakaian Kondom Untuk Mencegah Penularan PMS Dan Hiv Di Pati: Thesis FIK UI.

Mahaputra B, Lowndes CM, Mohanty SK, Gurav K, Ramesh BM, Moses S, Washington R, Alary M (2013). Factors Associated with Risky Sexual Practices among Female Sex Workers in Karnataka, India: A Literature Review. PLoS ONE 8(4): e62167.

Manlove J, Ikramullah E, Humen ET. (2008). Condom Use and Consistency Among Male Adolescents in the United States: A Literature Review. Journal of Adolescent Health 43(208): 325-333.

Murti B (2013). Desain Dan Ukuran Sampel Untuk Penelitian Kuantitatif Dan Kualitatif Di Bidang Kesehatan. Surakarta: Gadjah Mada University Press.

Profil Kesehatan Profinsi Jawa Timur Tahun 2012 Tentang Jumlah Kasus Baru HIV, AIDS dan Infeksi Menular Seksual Lainnya Menurut Jenis Kelamin dan Kabupaten/ Kota.

Profil Kesehatan Kabupaten Tulungagung Tahun 2010 Tentang Persentase Infeksi Menular Seksual Diobati.

Samra OM (2008). How to Use a Condom: Advocates for Youth. Washington DC.

Sembiring R, Sembiring F (2012). Pengaruh Predisposing Factor, Enabling Factor Dan Reinforcing Factor Terhadap Upaya Pencegahan Infeksi Menular Seksual Pada Wanita Pekerja Seks Komersial Di Lokalisasi Warung Bebek Serdang Bedagai. Kesmas: Jurnal Kesehatan Masyarakat Universitas Sari Mutiara Indonesia.
Shannon K, Strathdee S A, Shoveller J, Rusch M, Kerr T (2009). Structural Environmental Barriers to Condom Use Negotiation With Clients Among Female Sex Workers: Implications for Prevention Strategies and Policy, 99(4): 659-665.

Strathdee SA, Lozada R, Martinez G, Vera A, Rusch M, Nguyen L, Pollini RA, Salas FU, Beletsky L, Patterson TL (2011). Social and Structural Factors Associated with HIV Infection among Female Sex Workers Who Inject Drugs in the Mexico-US Border Region: A Literature Review. PLoS ONE 6(4): e19048.

Strathdee SA, Abramovitz D, Lozada R, Martinez G, Rangel MG, Vera A, Staines H, Rodriguez CM, Patterson TL (2013). Reductions in HIV/STI Incidence and Sharing of Injection Equipment among Female Sex Workers Who Inject Drugs: Results from a Randomized Controlled Trial: A Literature Review. PLoS ONE 8(6): e65812.

World Health Organization. (2008). 10 facts on sexually transmitted infections: Dept. of Reproductive Health and Research. Accessed 7 April 2016.

Widyastuti, Utami, Arifianti (2012). Faktorfaktor yang mempengaruhi tingginya kejadian IMS di Lokalisasi gang sadar Baturaden Banyumas: Jurnal Ilmiah Kebidanan, 3(1).

Yadav D, Ramanathan S, Goswami P, Ramakrishnan L, Saggurti L, Sen S, George B, Paranjape (2013). Role of Community Group Exposure in Reducing Sexually Transmitted Infection Related Risk among Female Sex Workers in India: A Literature Review. PLoS ONE 8(10). 